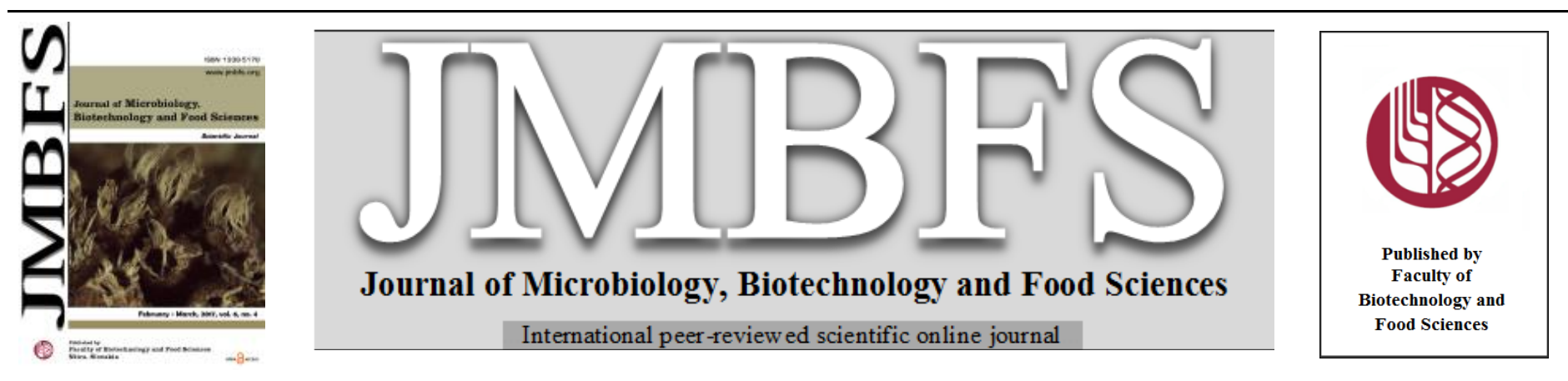

\title{
LACTIC ACID BACTERIA AND YEAST DIVERSITIES IN SPONTANEOUSLY FERMENTED MILLET SOURDOUGHS
}

\section{Stephen Abiola Akinola ${ }^{1}$ and Oluwatooyin Faramade Osundahunsi ${ }^{2}$}

\author{
Address(es): ${ }^{1} \mathrm{Mr}$ Stephen Abiola AKINOLA, \\ ${ }^{1}$ Federal University of Technology, Akure, School of Agriculture and Agricultural Technology, Department of Food Science and Technology, 235, 340001, Akure,
} Ondo State, +234706-780-3570.

*Corresponding author: akinolastephen3@gmail.com

doi: 10.15414/jmbfs.2017.6.4.1030-1035

\section{ARTICLE INFO}

Received 12. 6. 2016

Revised 24. 10. 2016

Accepted 1. 12. 2016

Published 1. 2. 2017

Regular article

OPEN $\partial_{\text {ACCESS }}$

\begin{abstract}
The lactic acid bacteria (LAB) and yeast diversities in spontaneously fermented pearl millet (Pennisetum glaucum) and finger millet (Eleusine coracona) sourdoughs were investigated. Pearl and finger millet grains were processed into flour and used in spontaneous sourdough fermentation. LAB and yeast cultures were isolated, screened and identified based on morphological, biochemical and sugar utilisation pattern using API 50CHL and API 20 AUX kits. Titratable acidity, $\mathrm{pH}$ and Temperatures of sourdoughs developed were also monitored. Titratable acidity and Temperature increased with increasing days of fermentation and conversely the $\mathrm{pH}$. and mesophilic bacterial count followed that of a normal bacterial growth curve. Dominant LAB and yeasts in pearl and finger millet spontaneously developed sourdoughs were Lb. plantarum, Lb. plantarum 1, Pediococcus pentosaseus, Lb. pentosus, and Saccharomyces cereviasiae. However, Candida milleri was found in pearl millet sourdoughs. The dominant cultures in millet sourdoughs could find applications as starter cultures if improved sourdough quality is desired.
\end{abstract}

\section{INTRODUCTION}

Millets are group of highly variable grasses with many small seeds. Pearl millet (Pennisetum glaucum) and Finger millet (Eleusine coracona) are among the most important ones grown in the tropics but underutilized. Sourdough is an acidic pastes laden with potentials to optimize desirable functional properties in flours. It is a technological process applied to non-gluten flours. It is the foremost cereal fermentation performed with almost any cereal (De Vust et al., 2002; Valcheva et al., 2006; Edema, 2011). Sourdough consists of mixture of flour and clean water. Sourness is achieved by the action of fermentative organisms such as the lactic acid bacteria genera. Lactic acid bacteria and yeasts metabolic activities accounts for the desirable changes observed in sourdoughs. Some metabolites of sourdough microflora includes among other; organic acids, carbondioxide, diacetyl and alcohols.

Spontaneous fermentation is the oldest form of fermentation, it is left to chance and it is the form of fermentation in most small scale fermentations in the developing countries (Holpzapfel, 2002). Spontaneous fermentations results in inconsistent product quality and hazards. Several species of microgranisms ranging from bacteria and fungi have been reported to colonize most cereal fermentations. Lactic acid bacteria (LAB) belonging to the genus - Lactobacillus have been isolated from sourdoughs and identified (Corsetti et al., 2004).

Sourdoughs are composed of diverse source of LAB and yeast species (De Vuyst and Neysen, 2005). Microflora dominants in substrates are geographical region, processing and handling dependent. The LAB and yeasts developing in the dough may originate from selected natural contaminants in the flour, water, starters added or from previous fermentation vessel. LAB and yeasts are the predominant microorganisms present in sourdoughs (Vogel et al., 1996; Steinkraus, 1996; 1997; Holzapfel et al., 1998; Lee, 1997; Oyewole, 1997). LAB's belong to several genera, this includes; Lactobacillus spp., Lactococcus spp., Leuconostoc spp., Oenococcus spp., Pediococcus spp., Streptococcus spp., Tetragenococcus spp., Aerococcus spp., Carnobacterium spp., Enterococcus spp., Vagococcus spp. and Weissella spp (De Angelis et al., 2007). Great variety exist in yeast cultures found in sourdough fermentation depending on degree of dough hydration, leavening temperature, sourdough maintenance temperature and type of cereal used (Hammes et al., 2004; Gobbetti et al., 1994). However, Lactobacillus and Saccharomyces genera have been reported to be the most dominant in sourdough fermentations.

Studies on the ecology of sourdough microflora may help in the understanding of the microbial dynamics and differences between groups of closely related microbial population in cereal (sourdough) fermentations. In most natural fermentation, starters used are poorly known. Therefore, isolation, characterization and identification of the microorganisms involved in cereal fermentation with prospective selection as starter cultures is important hence our investigation.

\section{MATERIALS AND METHODS}

\section{Sample Collection}

Pearl millet (Pennisetum glaucum) and finger millet (Eleusine coracona) were purchased from local market in Plateau state, Jos, Nigeria. Pearl and finger millet grains were cleaned, steeped, processed into flours and packaged in polyethylene bags for further analysis as shown in Fig. 1. The millet grains were steeped in water for two days (1:3 w/v ratios of seeds to the volume of steeping water), dried at $70{ }^{\circ} \mathrm{C}$ for $4 \mathrm{~h}$ in hot air oven (Laboratory oven. DHG 9101.1SA) and milled into flour using attrition mill (Atlas exclusive, Alzico Ltd mill). Flours were sieved using 60 mesh Standard US sieve and packaged.

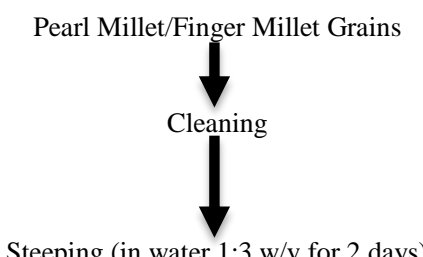

Steeping (in water $1: 3 \mathrm{w} / \mathrm{v}$ for 2 days)

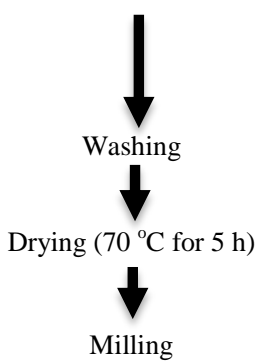




\section{1 \\ Sieving ( $\geq 60$ mesh sieve size or $0.22 \mathrm{~mm}$ mesh)
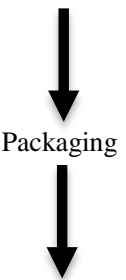 \\ Packaged Fermented Pearl millet/Finger millet flour}

Figure 1 Production of fermented pearl/finger millet flours

\section{Spontaneous Sourdough Development}

Sourdough were developed spontaneously from pearl and finger millet flours. Equal amounts of pearl and finger millet flours $(100 \mathrm{~g})$ and tap water $(100 \mathrm{ml})$ were mixed together using a glass stirrer in glass jars until a soupy consistency was achieved. Fermentation was allowed to proceed at ambient temperature $\left(29 \pm 2{ }^{\circ} \mathrm{C}\right)$ for seven days under anaerobic condition. Equal amount of fresh aliquots (millet flour and tap water) were added to the developing batter in the jars continously using a wooden spoon. This was done each day of the sourdough fermentation in order to refresh the fermentation medium (Edema and Sanni, 2006).

\section{Determination of $\mathrm{pH}$ and Temperature}

Changes in $\mathrm{pH}$ of spontaneously developed pearl and finger millet sourdoughs were monitored with increase in days of fermentation. Twenty milliliter of spontaneously developed pearl and finger millet sourdoughs were used for the determination. The $\mathrm{pH}$ was determined using a $\mathrm{pH}$ meter (ECO Testr $\mathrm{pH} 1)$ after standardising using $\mathrm{pH}$ buffer 4.0 and 7.0 respectively. The changes in temperature of the sourdough batters was determined from the same batch used for $\mathrm{pH}$ determination.

\section{Determination of titratable acidity}

Titratable acid produced in the sourdoughs was determined according to method described by Lonner et al. (1986). Briefly, from the same batch used for the $\mathrm{pH}$ and temperature determination, one (1) $\mathrm{g}$ of the fermenting millet sourdoughs were measured using an electronic digital balance into a conical flask and made up with distill water to $9 \mathrm{ml}$ mark. Ten (10) $\mathrm{ml}$ each of the homogenized samples were titrated against $1 \mathrm{~N} \mathrm{NaOH}$ using 2-3 drops of phenolphthalein indicator until endpoint was reached. The amount of $\mathrm{NaOH}$ used during the titration was expressed as total titratable acid produced. Each $\mathrm{ml}$ of $1 \mathrm{~N} \mathrm{NaOH}$ used is equivalent to $90.08 \mathrm{mg}$ of lactic acid.

\section{Microbial analysis}

\section{Enumeration and isolation of lactic acid bacteria and yeast from Sourdoughs}

The microbial analysis was carried out using pour plating methods as described by Harrigan and McCane (1976). From the spontaneously developed pearl and finger millet sourdoughs, one gram of each was homogenised in $9 \mathrm{ml}$ sterilized saline solution $(0.85 \% \mathrm{NaCl})$ and further diluted till a factor of nine was obtained. One (1) $\mathrm{ml}$ each of serially diluted homogenized samples was plated on sterilized de Mann Rogosa Sharpe (MRS) (Oxoid, PM221, USA) and Potatodextrose (EUR Pharm, Spain) agar. Cultured MRS plates were incubated anaerobically at $30^{\circ} \mathrm{C}$ for $48 \mathrm{~h}$ in an anaerobic jar loaded with gas pak (BBL Gas Pak, H2 \& CO2; Becton-dickinson, Cockeysville, MD, USA) while that of PDA plates were incubated in a fungi incubator at $25{ }^{\circ} \mathrm{C}$ for $72 \mathrm{~h}$. The microbial populations of the sourdoughs were enumerated each day of fermentation Isolation and sub-culturing was done until pure cultures were obtained. Dominant presumptive lactic acid bacteria and yeast cultures were further screened on the basis of cell morphological characteristics and biochemical (Gram reaction, catalase) characteristics using standard microbiological techniques as described by Harrigan and McCane, (1976); Fawole and Oso (2007)

Gram positive and catalase negative presumptive LAB isolates were screened for nitrate, urease, indole utilisation, gas production from glucose, spore formation, growth at different temperatures $\left(10{ }^{\circ} \mathrm{C}, 15{ }^{\circ} \mathrm{C}, 30{ }^{\circ} \mathrm{C}\right.$ and $\left.45{ }^{\circ} \mathrm{C}\right), \mathrm{NaCl}$ salt concentrations $(2 \%, 4 \%$ and $6.5 \%)$ and growth at different $\mathrm{pH}(4.5$ and 6.0$)$. The presumptive yeast cells were screened for growth at different $\mathrm{NaCl}$ salt concentration $(2 \%, 4 \%$ and $6.5 \%)$, growth at $37{ }^{\circ} \mathrm{C}$ and utilisation of urease Cultures were further characterised using carbohydrate fermentation pattern through the Analytical Profile Index (API Kit). The dominant presumptive lactic acid bacteria were characterised using API $50 \mathrm{CH}$ and API $50 \mathrm{CHL}$ medium (Biomerieux, France) while API $20 \mathrm{E}$ was used for the presumptive yeast isolates. The tray was moistened with sterile distilled water to prevent drying out and inoculum (actively growing culture) was dispensed into wells after equal McFarland concentration was achieved. McFarland concentration was achieved using UV-visible spectrophotometer at $290 \mathrm{~nm}$ wavelenght. Anaerobiosis was achieved in the API kits by overlaying inoculated tubes on trays with sterilised paraffin oil and incubated at $30{ }^{\circ} \mathrm{C}$ for $48 \mathrm{~h}$ while API $20 \mathrm{E}$ at $36{ }^{\circ} \mathrm{C}$ for $72 \mathrm{~h}$ Isolates were identified with reference to Bergey's Manual of Systematic Bacteriology (Wood and Holzapfel, 1995) and apiweb ${ }^{\mathrm{TM}}$ identification software (Biomerieux).

\section{RESULTS AND DISCUSSION}

Sourdough paste developed spontaneously from pearl and finger millet flour had a soupy consistency as the days of fermentation increased however, more frotting was observed in sourdough developed from finger millet which might be due to the metabolic activity of yeast in the sourdough. The finger millet flour absorbed more water compared to the pearl millet flour and this might be due to higher carbohydrate and fibre content in finger millet compared to pearl millet. Obilana (2003) reported the carbohydrate content of whole pearl and finger millet flour as $70 \mathrm{~g} / 100 \mathrm{~g}$ and $74 \mathrm{~g} / 100 \mathrm{~g}$ respectively and the crude fibre content as $2.3 \mathrm{~g} / 100 \mathrm{~g}$ and $3.6 \mathrm{~g} / 100 \mathrm{~g}$ respectively. Higher water absorption capacity is attributed to loose structure of starch polymers (Adebowale et al., 2008; Akinola et al., 2016).

Table 1 presents the morphological and biochemical characteristics of presumed lactic acid bacteria and yeast isolates from spontaneously developed pearl and finger millet sourdough. About $62.5 \%$ and $58.8 \%$ of presumptive bacteria isolates from pearl and finger millet sourdoughs were circular while $37.5 \%$ and $41.2 \%$ were irregular in shape respectively. This findings supports the previous work of Valík and Görner (1995) and Hutkins (2006). The colony surfaces of presumptive bacteria isolates were generally smooth except in P3, P4, F2 and F6 that were wrinkled. However, F8 had rough surface. The colony colour of presumptive bacteria isolates ranged from white, creamy, dull white and orange in finger millet isolates. All presumptive yeast isolates were non-motile, butyrous, creamy, smooth in surface. Most isolates from pearl and finger millet sourdoughs were catalase negative. Catalase negative is indicative of the isolates ability to hydrolyse hydrogen peroxide in producing catalase enzyme. All isolates were gram positive. The morphological characteristics observed in many of the isolates corroborate the findings of previous authors on lactic acid bacteria Wood and Holzapfel, (1995) described lactic acid bacteria as Gram-positive, non-spore forming, catalase-negative cocci or rods that are anaerobic, microaerophilic or aero-tolerant. Lactobacilli are Gram-positive, catalase-negative, non-sporing rods (whose cell length varies between $1.5 \mu \mathrm{m}$ and $5 \mu \mathrm{m}$. The cell may be slender, curved or bend when viewed under the microscope and may be in chains or network (Edema and Sanni, 2006; 2008). The shape of isolates under the light microscope were short rods in clusters, short rods, long rods in network, long rods and cocci. The isolates were non-spore formers and indole negative. This imply they are unable to hydrolyze tryptophan in producing indole. The isolates were unable to utilize urea and nitrate while some produced nitrogen gas. Homofermentative organisms produces only lactic acid from glucose, examples include $L$. lactis subsp lactis, L. lactis subsp diacetylactis and $L$. cremoris while the Heterofermentative produces lactic acid, carbondioxide and aroma compounds as product of fermentation, examples include Leuconostoc mesenteroides, Lactobacillus spp (Sanni et al., 1998). Many of the isolates had ability to produced gas from glucose. The isolates thrived at $15{ }^{\circ} \mathrm{C}$ and above. This current findings agrees with that of Hutkins, (2006) describing most bacteria isolates in sourdough as mesophilic, with some genuses having some species that are psychrotrophic, thermoduric or thermophilic. Some species are salt tolerant, acid tolerance, growing below $\mathrm{pH}$ 4.0. Lactic acid bacteria grows at an optimum $\mathrm{pH}$ of 5.5 - 6.5. Some strains are reported to be ethanol tolerant, biletolerant, aero-tolerant and some requiring strict anaerobic conditions (Petra et al., 2011).

The carbohydrate fermentation pattern of presumed lactic acid bacteria isolated from sourdough is presented in Table 2 . The result showed that $L b$. pentosus and $L b$. plantarum was most dominant cultures representing about twenty-five percent (25\%), P. pentosaseus, Micrococcus varians, Lb. buchneri and $L b$ amylovorus $(12.5 \%)$ each while Lb. plantarum and Lb. pentosus was the most dominant LAB in finger millet sourdough. The genera Lactobacillus, Lactococcus, Pediococcus and Leuconostoc have been reported important in food technology (Harrigan and McCane, 1976). The carbohydrate fermentation pattern of presumed yeasts isolates from pearl and finger millet sourdoughs is presented in Table 3. Results showed the dominance of Saccharomyces cerevisiae. Saccharomyces cerevisiae had weak reaction to mannitol, sorbose, sorbitol and esculin while Candida quercitrusa and C. milleri had weak reaction to trehalose and 2-keto-gluconate. Several yeast species has been reported in sourdoughs by various authors (Hammes et al., 2004; Rossi, 1996; De Vuyst and Neysens, 2005). The observed lactic acid bacteria and yeast isolates agrees with those observed in previous similar works. Jakobsen and Lei (2004); Achi (2005) and Kalui et al. (2009) reported the occurrence of L. plantarum, L. casei, L.sakei, L. acidophilus and L. salivarius in cereal based fermented food. Also, Kalui et al. (2009) reported the isolation of $L$. fermentum, $P$. pentosaceus, $L$. plantarum, $W$. confusus and $L$. rhamnosus from ikii- a traditional fermented 
$\underline{\text { Table } 1 \text { Morphological and biochemical characteristics of dominant presumed lactic acid bacteria and yeasts isolates from spontaneously developed pearl and finger millet sourdoughs }}$

\begin{tabular}{|c|c|c|c|c|c|c|c|c|c|c|c|c|c|c|c|c|c|c|c|c|c|c|c|c|}
\hline 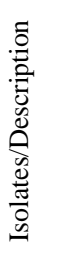 & 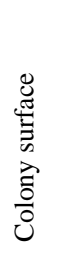 & 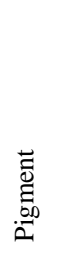 & 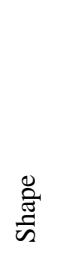 & 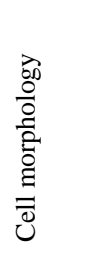 & 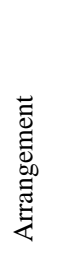 & 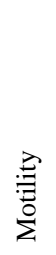 & $\begin{array}{l}0 \\
\text { 岕 } \\
\frac{\tilde{J}}{\tilde{J}} \\
\tilde{U}\end{array}$ & 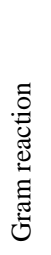 & $\begin{array}{l}0 \\
\text { ڤ̆ } \\
\text { के }\end{array}$ & $\begin{array}{l}\stackrel{\mathscr{J}}{\Xi} \\
\stackrel{5}{5}\end{array}$ & 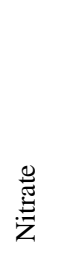 & $\begin{array}{l}\frac{0}{0} \\
\frac{0}{0}\end{array}$ & 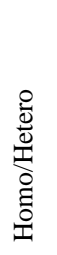 & 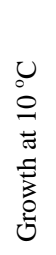 & 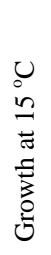 & 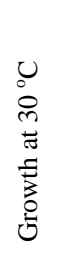 & 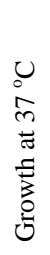 & 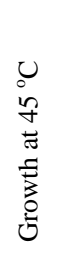 & 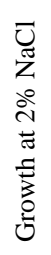 & 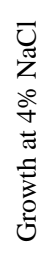 & $\begin{array}{l}\overline{0} \\
\tilde{z} \\
0 \\
0 \\
n \\
0 \\
\tilde{n} \\
\tilde{n} \\
0 \\
0 \\
0\end{array}$ & $\begin{array}{l}\stackrel{n}{+} \\
\stackrel{7}{T} \\
2\end{array}$ & $\begin{array}{l}0 \\
\dot{0} \\
\underline{I} \\
2\end{array}$ & 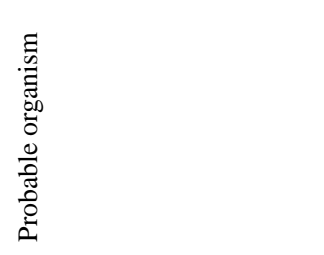 \\
\hline P1 & $\mathrm{Sm}$ & $\mathrm{Wh}$ & Cir & Rods & SS & - & - & + & - & - & $-\mathrm{NG}$ & - & Ho & - & - & + & nd & - & + & - & - & + & + & Lactobacillus pentosus \\
\hline P2 & $\mathrm{Sm}$ & Wh & Cir & Cocci & $\mathrm{CL}$ & - & - & + & - & - & $-\mathrm{NG}$ & - & Het & - & + & + & nd & - & + & + & - & + & + & Pediococus pentosaseus \\
\hline P3 & W & Wh & Irreg & Rods & SL & - & - & + & - & - & $\pm \mathrm{G}$ & - & Het & - & - & + & nd & + & - & + & + & + & \pm & Lactobacillus plantarum \\
\hline P4 & W & $\mathrm{C}$ & Irreg & Rods & SL & - & - & + & - & - & $\pm \mathrm{G}$ & - & Het & - & + & + & nd & + & + & + & - & + & \pm & Lactobacillus buchneri \\
\hline P5 & $\mathrm{Sm}$ & Wh & Cir & Cocci & $\mathrm{CL}$ & - & - & + & - & - & $-\mathrm{NG}$ & - & Het & - & + & + & nd & - & + & + & - & + & - & Micrococcus varians \\
\hline P6 & $\mathrm{Sm}$ & Wh & Cir & Rods & $\mathrm{SC}$ & - & - & + & - & - & $-\mathrm{NG}$ & - & Ho & - & - & + & nd & + & + & + & - & + & \pm & Lactobacillus amylovorus \\
\hline $\mathrm{F} 1$ & $\mathrm{Sm}$ & Wh & Cir & Rods & SS & - & - & + & - & - & $-\mathrm{NG}$ & - & Ho & - & - & + & nd & - & + & + & - & + & + & Lactobacillus pentosus \\
\hline $\mathrm{F} 2$ & $\mathrm{~W}$ & $\mathrm{C}$ & Irreg & Rods & SL & - & - & + & - & - & $+\mathrm{G}$ & - & Het & - & + & + & nd & + & + & + & - & + & \pm & Lactobacillus plantarum 1 \\
\hline F3 & $\mathrm{Sm}$ & $\mathrm{C}$ & Cir & Rods & SS & - & - & + & - & \pm & $+\mathrm{G}$ & - & Ho & - & + & + & nd & - & + & + & + & + & + & Lactobacillus farciminis \\
\hline $\mathrm{F} 4$ & $\mathrm{Sm}$ & $\mathrm{C}$ & Cir & Rods & SS & - & - & + & - & \pm & $+\mathrm{G}$ & - & Ho & - & + & + & nd & - & + & + & + & + & + & Lactobacillus farciminis \\
\hline F5 & $\mathrm{Sm}$ & Wh & Cir & Rods & $\mathrm{SC}$ & - & - & + & - & - & $-\mathrm{NG}$ & - & Ho & - & - & + & nd & + & + & + & - & + & \pm & Lactobacillus amylovorus \\
\hline F6 & W & Wh & Irreg & Rods & SL & - & - & + & - & - & $\pm \mathrm{G}$ & - & Het & - & - & + & nd & + & - & + & + & + & \pm & Lactobacillus plantarum \\
\hline F7 & $\mathrm{Sm}$ & Wh & Irreg & Rods & $\mathrm{SC}$ & - & - & + & - & - & $-\mathrm{NG}$ & - & Het & - & + & + & nd & - & + & + & + & - & - & Lactobacillus alimentarius \\
\hline F8 & $\mathrm{R}$ & Wh & Cir & Cocci & $\mathrm{CL}$ & - & - & + & - & - & $-\mathrm{NG}$ & - & Het & - & + & + & nd & + & - & - & - & + & + & Pediococcus pentoaseus 1 \\
\hline F9 & $\mathrm{Sm}$ & Wh & Cir & Rods & SS & - & - & + & - & - & $-\mathrm{NG}$ & - & Ho & - & - & + & nd & + & - & - & - & + & + & Lactobacillus crispatus \\
\hline PY1 & $\mathrm{Sm}$ & $\mathrm{C}$ & Cir & Oval & EL & - & + & + & - & + & nd & nd & nd & nd & nd & nd & + & nd & + & + & + & nd & nd & Saccharomyces cerevisiae \\
\hline PY2 & $\mathrm{Sm}$ & $\mathrm{C}$ & Cir & Oval & EL & - & + & + & - & + & nd & nd & nd & nd & nd & nd & + & nd & + & + & + & nd & nd & Candida quercitrusa \\
\hline PY3 & $\mathrm{Sm}$ & $\mathrm{C}$ & Cir & Oval & EL & - & + & + & - & + & nd & nd & nd & nd & nd & nd & + & nd & + & + & + & nd & nd & Candida milleri \\
\hline PY4 & $\mathrm{Sm}$ & $\mathrm{C}$ & Cir & Oval & EL & - & + & + & - & + & nd & nd & nd & nd & nd & nd & + & nd & + & + & + & nd & nd & Saccharomyces cerevisiae \\
\hline FY1 & $\mathrm{Sm}$ & $\mathrm{C}$ & Cir & Oval & EL & - & + & + & - & + & nd & nd & nd & nd & nd & nd & + & nd & + & + & + & nd & nd & Saccharomyces cerevisiae \\
\hline FY2 & $\mathrm{Sm}$ & $\mathrm{C}$ & Cir & Oval & EL & - & + & + & - & + & nd & nd & nd & nd & nd & nd & + & nd & + & + & + & nd & nd & Saccharomyces cerevisiae \\
\hline FY3 & $\mathrm{Sm}$ & $\mathrm{C}$ & Cir & Oval & EL & - & + & + & - & + & nd & nd & nd & nd & nd & nd & + & nd & + & + & + & nd & nd & Saccharomyces cerevisiae \\
\hline
\end{tabular}

Key: $+=$ positive reaction, $-=$ negative reaction, $\pm=$ Weak reaction, $+\mathrm{G}=$ Positive and gas production, $-\mathrm{NG}=$ Negative and no gas production, $\pm \mathrm{G}=\mathrm{Weak}$ reaction and gas production, $\mathrm{Sm}=$ Smooth, $\mathrm{W}=$ wrinkled, $\mathrm{R}=$ Rough, $\mathrm{Cir}=$ Circular, $\mathrm{Wh}=$ White, $\mathrm{C}=$ Creamy, Irreg = Irregular, $\mathrm{SS}=$ Short and Singly, $\mathrm{CL}=\mathrm{Clusters,} \mathrm{SL}=\mathrm{Short}$ and long, $\mathrm{SC}=\mathrm{Short}$ and in $\mathrm{Clusters,} \mathrm{EL}=$ Ellipsoidal, nd $=$ not determined. 
$\underline{\text { Table } 2}$ The carbohydrate fermentation pattern of dominant presumed lactic acid bacteria isolates obtained from spontaneously developed pearl and finger millet sourdoughs

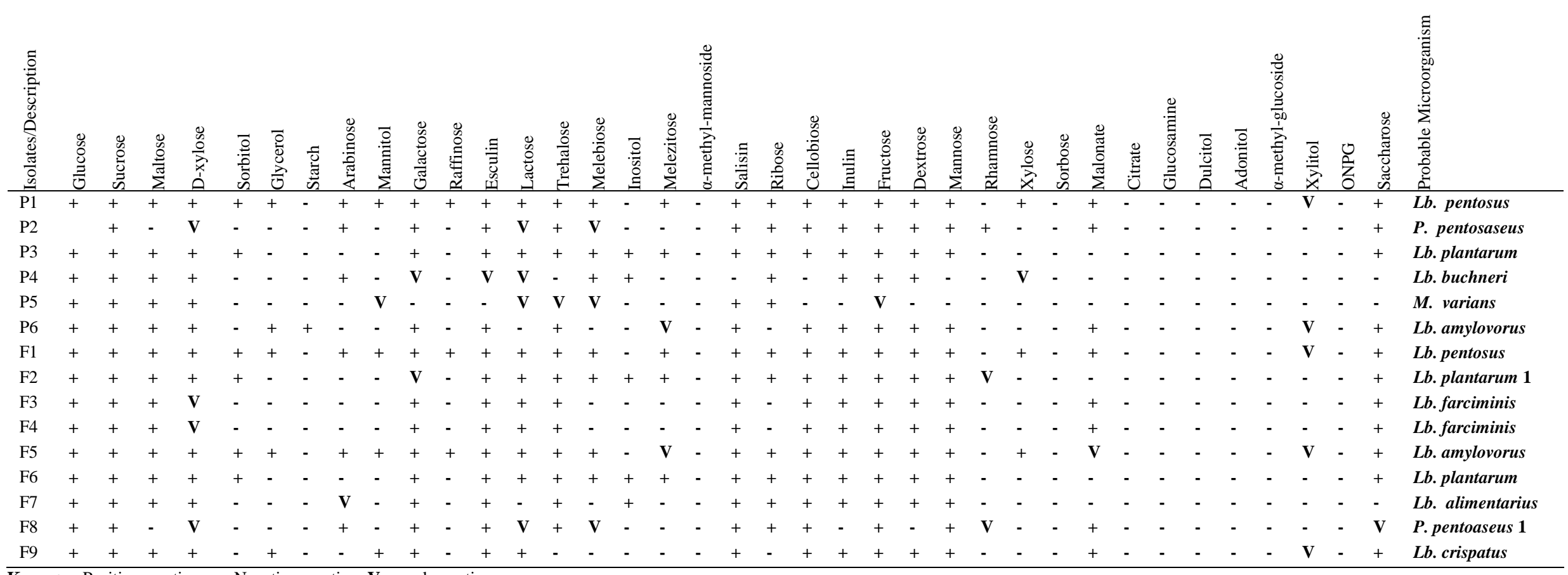

Keys: + = Positive reaction, - = Negative reaction, $\mathbf{V}=$ weak reaction,

$\underline{\text { Table } 3 \text { The carbohydrate fermentation pattern of dominant presumed yeasts isolates obtained from spontaneously developed pearl and finger millet sourdoughs }}$

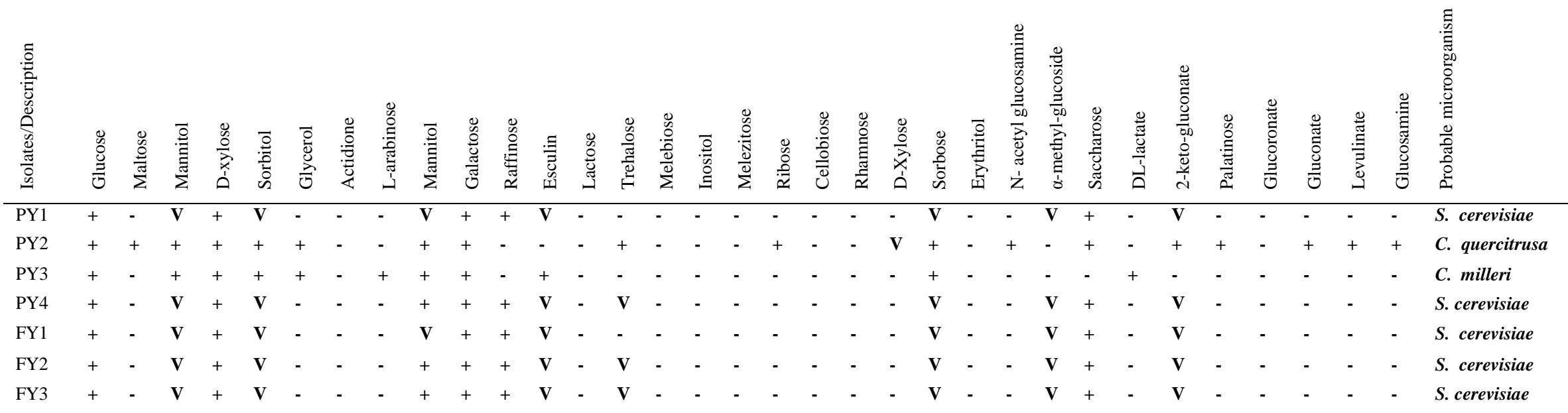

Keys: + = Positive reaction, - = Negative reaction, $\mathbf{V}=$ weak reaction. 
maize porridge in Kenya. The number and type of yeast species found in sourdoughs depends on several factors including the degree of dough hydration and type of cereal used. The dominance of $S$. cerevisiae might be due to its ability to utilise simple sugar in the cereals faster during fermentation.

Fig. 2 and 3 presents the mean $\mathrm{pH}$, temperature and titratable acidity of spontaneously developed sourdoughs from pearl and finger millet. From Figure 2 and figure 3 , the $\mathrm{pH}$ of the spontaneously developed sourdoughs decreased with increasing days of fermentation. The $\mathrm{pH}$ ranged from 4.9 to 3.5 in pearl millet sourdough while in finger millet sourdough it ranged from 5.7 to 3.3. This agrees with results obtained by Sanni et al. (1998) in a work on sour maize bread production using starter cultures. The significant decrease in $\mathrm{pH}$ might be due to increase acid production by lactic acid bacteria in the sourdough. No significan difference was observed in the $\mathrm{pH}$ of the pearl millet sourdoughs on the 6th and 7 th day of fermentation.

The temperature of the spontaneously developed pearl and finger millet sourdoughs increased with increasing days of fermentation. This might be due to increased rate of reaction in the sourdough as metabolites production increased Temperature increases from $27{ }^{\circ} \mathrm{C}$ to $32{ }^{\circ} \mathrm{C}$ in sour maize bread produced by Sanni et al. (1998) however, after $48 \mathrm{~h}$ of fermentation the temperature was constant at $32{ }^{\circ} \mathrm{C}$ and the $\mathrm{pH}$ reduced further to 3.7. Hounhouigan et al. (1993) reported titratable acidities ranging from 1.2 - 1.4 in 'mawe', a fermented maize dough. Titratable acidities increased significantly with increasing days of fermentation. Titratable acidity ranged from $1.5 \mathrm{ml}$ to $3.4 \mathrm{ml}$ and $1.1 \mathrm{ml}$ to $3.6 \mathrm{~m}$ in spontaneously developed pearl and finger millet sourdoughs. The dominant metabolite of lactic fermentation is lactic acid although acetic acid also contributes to acidification (Petra et al., 2011). Acetic acid is important for strong aroma, fungicidal and antimicrobial effect in fermented products while lactic acid influences product texture (Corsetti and Settanni, 2007).

Fig 4 and 5 presents the microbial population of mesophilic bacteria and fungi of spontaneously developed pearl and finger millet sourdoughs. The mesophilic bacterial count increased with increasing fermentation days. The bacteria count of pearl and finger millet sourdough ranged from $53 \times 10^{8}-280 \times 10^{8} \mathrm{Cfu} / \mathrm{m}$ and $28 \times 10^{9} \mathrm{cfu} / \mathrm{ml}-50 \times 10^{9} \mathrm{cfu} / \mathrm{ml}$ respectively. The bacterial count of developed finger millet sourdough was highest on day 4 of fermentation. The fungi growth increased with increasing days of fermentation. The growth pattern of associated microorganisms followed a normal bacterial growth curve. This could be that the microbes were still in an adaptation phase (Lag phase) between the first two days of fermentation. At day 2 and 3 the mesophilic bacterial coun increased (exponential phase) which might be due to the activity of the microbes in adjusting to the new environment of fermentation. At day 4 and 5, the mesophilic bacterial count declined, this might be due to accumulation of metabolites, increased competition for limited nutrient resulting in death of the microorganisms. The bacteria involved in sourdough fermentations are mainly mesophilic (De-vuyst and Neysens, 2005). The microflora population of cereals flours ranged from $2 \times 10^{4}-6 \times 10^{6} \mathrm{CFU} / \mathrm{g}$ (Stolz, 1999). The occurrence of yeasts up to $2 \times 10^{3} \mathrm{CFU} / \mathrm{g}$ have been reported in cereals flours (De-vuyst and Neysens, 2005). The values obtained in this study are slightly higher than those reported by Stolz, (1999). The higher population of microbial counts might be due to pretreatment of the grains (fermentation).

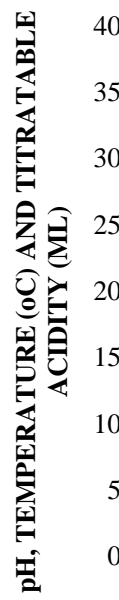

35
30
25
20
15
10
5
0
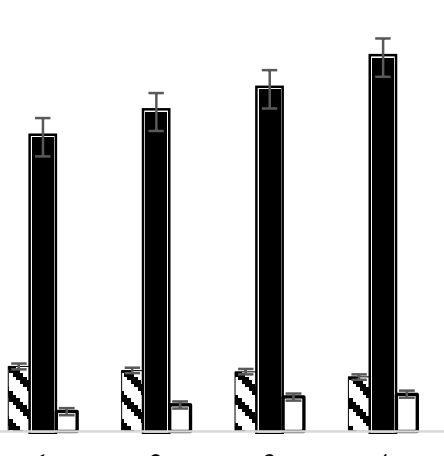

DAYS OF FERMENTATION

$\square \mathrm{Ph} \quad \square$ TEMPERATURE (OC) 口TTA (ML)

Figure $2 \mathrm{pH}$, Temperature $\left({ }^{\circ} \mathrm{C}\right)$ and Titratable acidity $(\mathrm{ml})$ of spontaneously developed sourdough from Pearl millet flour
40

35

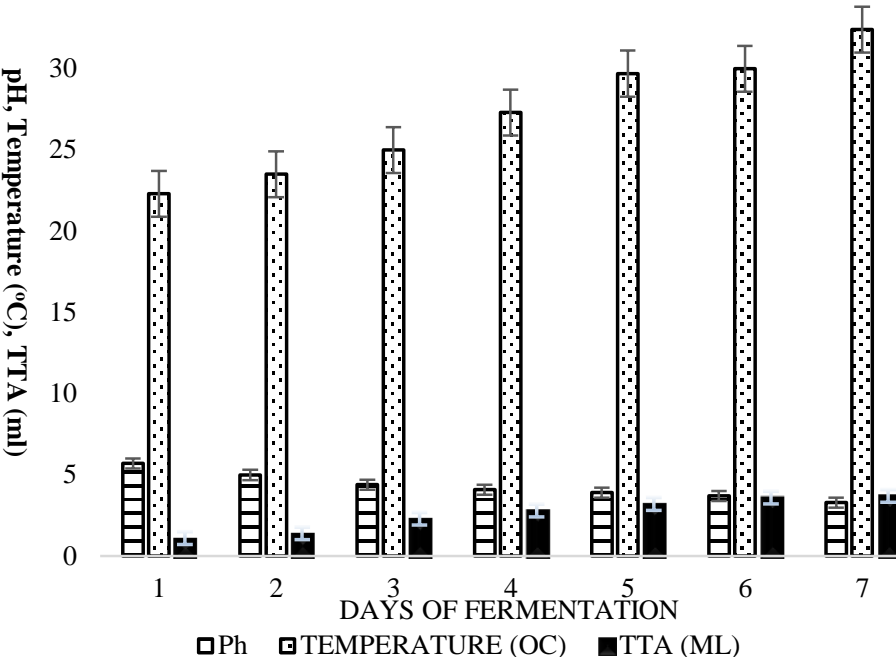

Figure $3 \mathrm{pH}$, Temperature $\left({ }^{\circ} \mathrm{C}\right)$ and Titratable acidity $(\mathrm{ml})$ of spontaneously developed sourdough from Finger millet flour

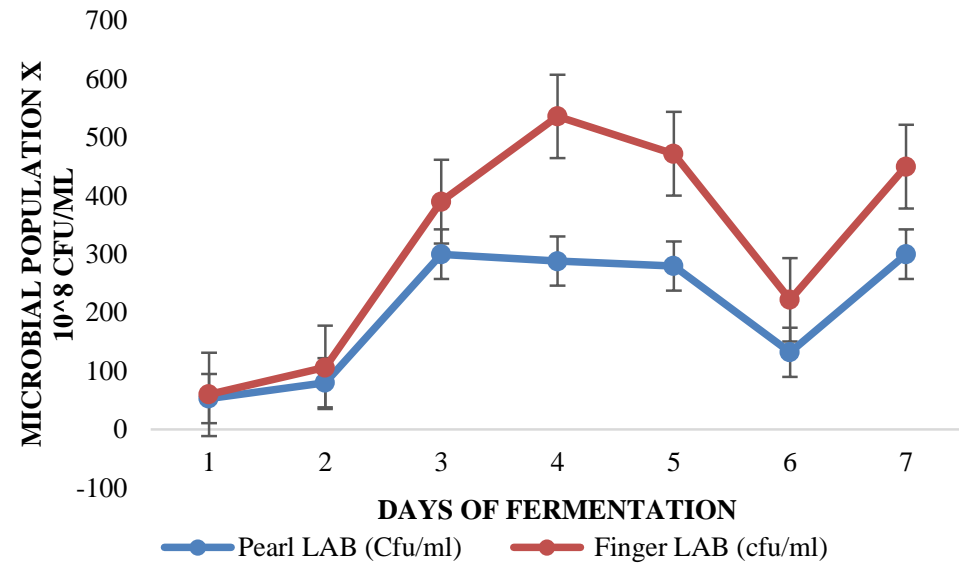

Figure 4 The microbial population of LAB isolated from spontaneously developed sourdough using pearl and finger millet flour

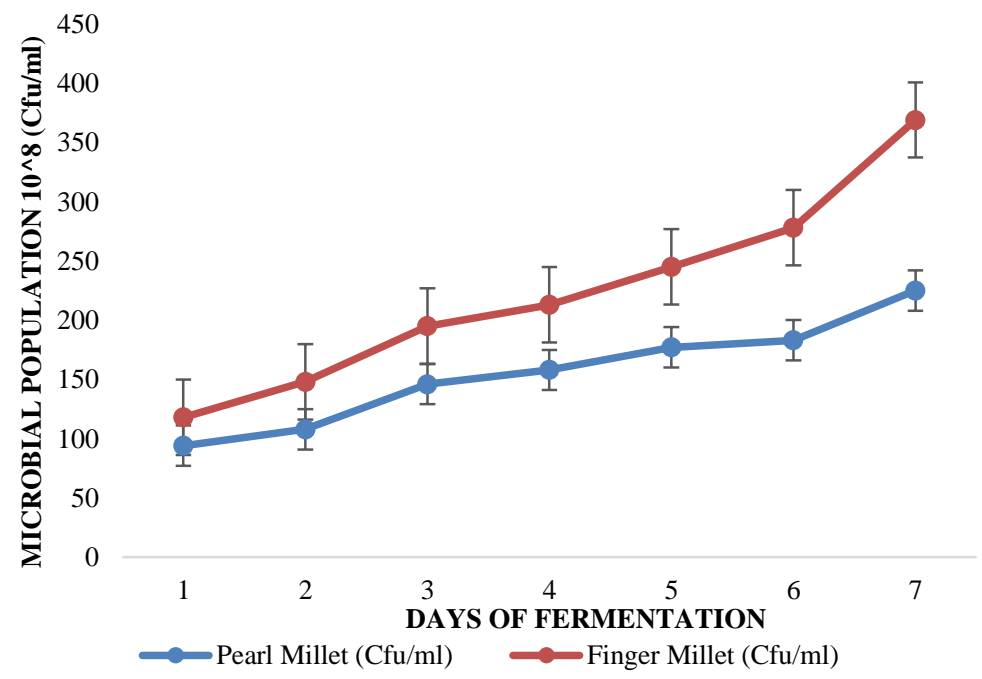

Figure 5 The microbial population of yeast isolated from spontaneously developed finger and pearl millet flour sourdough

\section{CONCLUSION}

Pearl and finger millet flour are rich sources of beneficial microbial consortia especially LAB and yeast. The titratable acidity, $\mathrm{pH}$, temperatures of fermenting millet meals increased with increasing days of fermentation. Spontaneously developed pearl millet sourdoughs were dominated by $L b$. plantarum (Heterofermenters) and Lb. pentosus, P. pentosaseus (Homofermenters) while 
spontaneously fermented finger millet sourdoughs is dominated by $\mathrm{Lb}$. plantarum 1, Lb. pentosus and $P$. pentosaseus. $S$. cerevisiae and Candida milleri are dominant yeast cultures in millet sourdoughs. Further studies should be done on the characterisation of microbial isolates using molecular techniques and screening of isolated cultures for desirable sourdough functional properties.

\section{REFERENCES}

ACHI, O.K., 2005. The potential for upgrading traditional fermented foods through biotechnology. Afr. J. Biotechnol. 4(5): 375-380. http://dx.doi.org/10.5897/AJB2005.000-3070

ADEBOWALE, A.A., SANNI, L.O., ONITOLO, M.O., 2008. Chemica composition and pasting properties of Tapioca grits from different cassava varieties and roasting methods. African Journal of Food Science, 2:77-82.

AKINOLA, S.A. BADEJO, A.A., OSUNDAHUNSI, O.F., EDEMA, M.O. 2016. Effect of Pre-Processing Techniques on Pearl Millet Flour and Changes in Technological Properties. IJFST. (In press). http://dx.doi.org/10.1111/ijfs.13363

CORSETTI, A., SETTANNI, L., 2007. Lactobacilli in sourdough fermentation Food Research international $40 \quad 40$ 558. http://dx.doi.org/10.1016/i.foodres.2006.11.001

CORSETTI, A., SETTANI, L.,VAN SINDEREN, D., 2004. Characterization of bacteriocin-like inhibitory substances (BLIS) from sourdough lactic acid bacteria and evaluation of their in vitro and in situ activity. J. Appl Microbiol 96: 521 536. http://dx.doi.org/10.1111/j.1365-2672.2004.02171.x

DE ANGELIS M., DI CAGNO, R., GALLO, G., CURCI, M., SIRAGUSA, S., CRECCHIO, C., PARENTE, E., GOBBETTI, M., 2007. Molecular and functional characterization of Lactobacillus sanfrancisiences strains isolated from sourdough. International Journal of Food Microbiology 114 (1): 69-82 http://dx.doi.org/10.1016/j.ijfoodmicro.2006.10.036

DE VUYST, L., NEYSENS, P., 2005. The sourdough microflora: biodiversity and metabolic interactions, Trends in Food Science \& Technology 16: 43-56. http://dx.doi.org/10.1016/j.tifs.2004.02.012

DE VUYST, L., SCHRIJVERS, V., PARAMITHIOTIS, S., HOSTE, B., VANCANNEYT, M., SWINGS, J. 2002. The biodiversity of lactic acid bacteria in Greek traditional wheat sourdoughs is reflected in both composition and metabolite formation. Applied and Environmental Microbiology, 68: 6059-6069. http://dx.doi.org/10.1128/aem.68.12.6059-6069.2002

EDEMA M.O., 2011. A Modified Sourdough Procedure for Non-Wheat Bread from Maize Meal. Food Bioprocess Technology 4:1264-1272. http://dx.doi.org/10.1007/s11947-009-0252-5

EDEMA, M. O., SANNI, A. I., 2006. Micro-population of fermenting maize meal for sour maize bread production in Nigeria. Nigerian Journal of Microbiology 20 (2):937 - 946.

EDEMA, M. O., SANNI, A. I., 2008. Functional properties of selected starte cultures for sour maize bread. Food Microbiology 25: 616 625.http://dx.doi.org/10.1016/j.fm.2007.12.006

FAWOLE, M.O., OSO, B.A., 2007. Characterisation of Bacteria: Laboratory Manual of Microbiology. Revised Ed. Spectrum Book Limited 24-33 Pp. Ibadan, Nigeria.

GOBBETTI, M., CORSETTI A. ROSSI, J., 1994. The sourdough microflora. Interactions between lactic acid bacteria and yeasts: metabolism of amino acids J. Microbiol. Biotechnol.,10: 275-279. http://dx.doi.org/10.1007/bf00414862

HAMMES, W. P., BRANDT, M. J., FRANCIS, K. L., ROSENHEIM, J., SEITTER, M. F. H., VOGELMANN, S. A. 2004. Microbial ecology of cerea fermentations. Trends in Food Science and Technology, 16(1-3):4-11. http://dx.doi.org/10.1016/j.tifs.2004.02.010

HARRIGAN W. F., MCCANE M. F. 1976, Laboratory Methods in Food and Dairy Microbiology. Revised Edition. 452 S., 24 Abb. Academic Press. London-New York, San Francisco. http://dx.doi.org/10.1002/jobm.3630180316 HOLZAPFEL, W.H., 2002. Appropriate starter culture technologies for smallscale fermentation in developing countries. International Journal of Food Microbiology 75: 197- 212. http://dx.doi.org/10.1016/s0168-1605(01)00707-3 HOLZAPFEL, W.H., HABERER, P., SNEL, J., SCHILLINGER, U. HUIS IN'T VELD, J.H.J., 1998. Overview of gut flora and probiotics. International Journal Food Microbiology. 41: 85- 101. http://dx.doi.org/10.1016/s01681605(98)00044-0

HOUNHOUIGAN, D.J., ROBERTONOUT, M.J., NAGO, C.M., HOUBEN, J.H., ROMBOUTS, F.M. 1993. Composition and microbiological and physical attributes of mawe, a fermented maize dough from Benin. International Journal of Food Science \& Technology 28: 513-517. DOI http://dx.doi.org/10.1111/j.1365-2621.1993.tb01300.x

HUTKINS, R.W., 2006. Microbiology and Technology of Fermented Foods, $1^{\text {st }}$ Ed. IFT Press, Blackwell Publishing Oxford. 475 p., ISBN: 978-0-8138-0018-9. http://dx.doi.org/10.1002/9780470277515

JAKOBSEN, M., LEI, V., 2004. Microbiological characterization and probiotic potential of koko and koko sour water, African spontaneously fermented millet porridge and drink. J. Appl Microbiol. 96(2): 384-397. http://dx.doi.org/10.1046/i.1365-2672.2004.02162.x

KALUI, C.M., MATHARA, J.M., KUTIMA, P.M., KIIYUKIA, C., WONGO L.E., 2009. Functional characteristics of Lactobacillus plantarum and
Lactobacillus rhamnosus from ikii, a Kenyan traditional fermented maize porridge. Afr. J. Biotechnol. 8(17): 4363-4373.

LEE, C.H., 1997. Lactic acid fermented foods and their benefits in Asia. Food Control 8: 259- 269. http://dx.doi.org/10.1016/S0956-7135(97)00015-7

LONNER, C., WELANDER, T., MOLIN, N., DOSTALEK, M. 1986. The micro-flora in a sourdough started spontaneously on typical Swedish rye meal. Food Microbiology, 3:3-12. http://dx.doi.org/10.1016/s0740-0020(86)80019-3

OBILANA, A.B., 2003. Overview: Importance of millet in Africa. ICRISAT, Nairobi Kenya 6pp.

OYEWOLE, O.B.1997. Lactic fermented foods in Africa and their benefits. Food Control 8: 289-297. http://dx.doi.org/10.1016/S0956-7135(97)000753

PETRA, G., ZUZANA, P., ERNEST, S, 2011. Importance of lactobacilli for bread-making industry,Acta Chimica Slovaca, 4 (2), 118 - 135.

ROSSI, J. 1996. The yeasts in sourdough. Advances in Food Science, 18, 201211.

SANNI, A.I., ONILUDE, A.A., FATUNGASE, M.O. 1998. Production of sour maize bread using starter-cultures. World Journal of Microbiology \& Biotechnology 14: 101-106. http://dx.doi.org/10.1023/a:1008836803338

STEINKRAUS, K. H. 1996. Handbook of indigenous fermented foods. 2nd Ed., Marcel Dekker, New York $792 \quad$ pp. ISBN 0824793528. http://dx.doi.org/10.1016/s0308-8146(96)80479-1

STEINKRAUS, K.H., 1997. Classification of fermented foods: worldwide review of household fermentation techniques. Food Control 8: $311-317$ http://doi:10.1016/S0956-7135(97)00050-9

STOLZ, P., 1999. Mikrobiologie des Sauerteiges: In G. Spicher, \& H. Stephan Eds., Handbuch Sauerteig: Biologie, Biochemie, Technologie 5th ed. Behr's Verlag. Hamburg, 35-60 pp.

VALCHEVA, R., FERCHICHI, M., KORAKLI, M., IVANOVA, I., GÄNZLE, M. G., VOGEL, R. F. 2006. Lactobacillus nantensis sp. nov. isolated from French wheat sourdough. International Journal of Systematic and Evolutionary Microbiology, 56: 587-591. http://dx.doi.org/10.1099/ijs.0.63619-0

VALÍK, L., GÖRNER F., 1995. Effect of water activity adjusted with different solutes on growth and lactic acid production by Lactobacillus helveticus. Folia Microbiologica 40 (5 ):472- 474. http://dx.doi.org/10.1007/bf02814725

VOGEL, R.F., MÜLLER, M., STOLZ, P., EHRMANN, M., 1996. Ecology in sourdoughs produced by traditional and modern technologies. Advances in Food Science 18 (5-6): 152-159.

WOOD, B.J.B., HOLZAPFEL, W.H., 1995. The Lactic Acid Bacteria: The Genera of Lactic Acid Bacteria, 1st edition. Chapman and Hall. London, http://dx.doi.org/10.1007/978-1-4615-5817-0 